\title{
Regional Development and Proximity Relations
}

Edited by André Torre and Frédéric Wallet, INRA - Agroparistech, Paris, France

New Horizons in Regional Science series, Edward Elgar Publishing

Introduction: The Role of Proximity Relations in Regional and Territorial Development Processes

André Torre and Fred Wallet

PART I: PROXIMITY AND REGIONAL DEVELOPMENT: MAIN DEBATES AND CONCEPTUAL PERSPECTIVES

1. Proximity and Endogenous Regional Development

Robert J. Stimson

2. Proximity Relations at the Heart of Territorial Development Processes

André Torre

3. Relatedness and Transversality in Spatial Paradigms and Regimes

Phil Cooke

PART II: THE ROLE OF PROXIMITY IN SPATIAL INNOVATION PROCESSES

4. Proximity and Regional Innovation Process: Is There Space for New Reflections?

Roberta Capello

5. When Local Interaction Does Not Suffice: Sources of Firm Innovation in Urban Norway

Rune Dahl Fitjar and Andres Rodriguez-Pose

6. How I Met My Partner. Reconsidering Proximities

Olivier Bouba-Olga, Michel Grossetti and Marie Ferru

PART III: NETWORKS AND PROXIMITY RELATIONS

7. The Formation of Economic Networks: A Proximity Approach

Ron Boschma, Pierre Alexandre Balland and Mathijs de Vaan

8. Digital Infrastructure and Physical Proximity

Peter Nijkamp and Emmanouil Tranos

9. Proximity Relations and Global Knowledge Flows: Specialization and Diffusion Processes across Capitalist Varieties

Rachael Gibson and Harald Bathelt 


\section{PART IV: PLACE-BASED STRATEGIES AND PROXIMITY RELATIONS}

10. The Regional Policy Debate: A Territorial, Place-based and Proximity Approach Roberto Camagni

11. Economic Development, Place-based Development Strategies and the Conceptualization of Proximity in European Urban Regions

Teodora Dogaru, Frank van Oort and Mark Thissen

\section{PART V: CONCLUSIONS}

12. A Challenging Book: Regional Development and Proximity Relations Antoine Bailly 